\title{
Wanting It All: The Challenge of US Health System Reform
}

\author{
Theodore Marmor ${ }^{*}$
}

\section{INTRODUCTION}

The background for this essay is hardly obvious. The Federal Reserve Board of Boston is not a group with which I have had any disciplinary or policy connection. I am a practicing political scientist with a long history of interest in health care and social insurance. I was, in short, surprised at being asked to introduce a conference on American health care reform that would be awash with papers by health economists.

I also faced a personal challenge in how to approach my subject-the politics of struggles to reform American medical care. There was the undeniable impulse to settle scores. After all, I had debated with most of the health economists in the conference for more than three decades. I had reviewed their books or articles in ways neither their spouses nor their parents would have approved, arguing with them in print and in debates about the limits rather than the benefits of market instruments and free-market allocational principles in medical care. The question for me was, what constructive essay could come out of that background? Indeed, to be utterly candid, my first thought was to imagine a virus that took out "consumer choice" and "market forces" from Alain Enthoven's computer. Or perhaps I could do the same thing to David Cutler, but choose "paying physicians for improved health outcomes" as the object of his computer virus. There is undeniable competition in the health policy game, and one competes in that game partly by product differentiation-that is, differentiation in policy ideas.

Due in part because I became Medicare-eligible last year, I thought this opening paper was a time for reflection, not retaliation. After all, I

\footnotetext{
- Theodore Marmor is professor of politics, public policy and law at Yale, coauthor of AMERICA'S MISUNDERSTOOD WELFARE STATE (1992), and author of UNDERSTANDING HEALTH CARe Reform (1994) and The Politics of Medicare (Aldine de Gruyter ed., 2d ed. 2000). An earlier version of this essay was delivered as a speech to the Federal Reserve Bank of Boston's annual public policy conference in 2005.
} 
was asked to discuss my specialty - the politics of health care-and the real question was, what helpful contribution could I offer to the health reform topic? So let me proceed with a brief sketch of the politics of American health reform, and then turn to my modest suggestion of a different way in which policy analysts might combine to improve the possibility of constructive policy change.

\section{HEALTH SySTEM REFORM-A STORY OF LONG-TERM ASPIRATION AND DEEP FRUSTRATION}

\section{A. The Politics of Universal Health Insurance: Lessons from the Past?}

Americans, without much qualification, are not particularly well served by their current medical care arrangements. In comparison with our major trading partners and competitors, we are less likely to be insured for the cost of care, and the care that we receive is almost certain to be more costly. Although American medicine has produced many "miracles," we are not the undisputed leader in medical innovation, only in the costliness and ubiquity of high-technology medicine. Most Americans "covered" by some form of health insurance still worry about its continuation should we or a close family member become seriously ill. Some of us are "locked into" employment we would gladly leave but for the potential catastrophic loss of existing insurance coverage. ${ }^{1}$

While most commentators decry our peculiar ability to combine insecurity with high cost, the substantial reform of American medicine at the national level has been enormously difficult to achieve, and comprehensive reform has been impossible. This is not simply a description of the Clinton Health Plan debacle of 1993-94. On multiple occasions before and after the Second World War, comprehensive national reform has been attempted (and between 1973-74, appeared imminent). In all those instances, reform fell short of the necessary political majorities. Each of those failures has its own peculiar history, and in each there are many contributing causes of the failure. ${ }^{2}$

1. These generalizations hold up even if everything David Cutler and Bill Nordhaus assert in their chapters about the benefits of medical improvement is true. In comparison, our mix of cost, quality, and access leaves a majority of Americans spending more and feeling bad about the mix.

2. See Theodore Marmor, The Politics of Universal Health Insurance: Lessons from Past Administrations?, 27 POL. SCI. \& POL. 194 (1994) (discussing the failure of health reform initiatives in America); see generally OdIN W. ANDERSOn, HeAlth SERVICES IN THE UNITEd STATES: A GROWTH ENTERPRISE SINCE 1875 (1985) (giving the general history of health services from 1875 to the present); Eli Ginzberg, The Medical Triangle: Physicians, Politicians, and the Public (1990) (analyzing social factors influencing the development of health care systems since World 
Americans have been long dissatisfied with the nation's medical arrangements, but our political system has been unable to come up with a solution that satisfies enough of the public to overwhelm the other institutional and interest group barriers to substantial, publicly directed reform. $^{3}$

There is now once again a remarkable consensus that American medical care-particularly its financing and insurance coverage-needs a major overhaul. The critical unanimity on this point-what Paul Starr once rightly termed a "negative consensus"-bridges almost all the usual cleavages in American politics-between old and young, Democrats and Republicans, management and labor, the well paid and the low paid. ${ }^{4}$ We spend more on, and feel worse about, medical care than our economic competitors, with the overwhelming majority of Americans (including Fortune 500 executives) telling pollsters that our medical system requires substantial change. That level of public discontent was, in 1993 as in 2005, good news for medical reformers. ${ }^{5}$

There was bad news for reformers then as there is now. For a variety of ideological and institutional reasons, American politics makes it very difficult to coalesce around a solution that reasonably satisfies the requirements for a stable and workable system of financing and delivering modern medical care. We have no assurance that agreement on the seriousness of the nation's medical ills will generate the legislative support required for a substantively adequate and

War II); Paul StarR, THE SOCIAl TRansformation of AMERICAN MEdicine (1982) (discussing the history of medical care from colonial times to the present).

3. While substantial change took place in the United States in the decades from 1980 to 2000 , most of it was privately generated. What is called the "managed care" movement altered the way most American physicians practice and get paid and had a lot to do with the changing ownership and shape of American hospitals. These changes stand in contrast to the publicly organized reforms in the UK (internal markets in the 1990s) or Canada (national health insurance in the period 1957-71). For more on health reforms, especially "nonpublic change," see generally CAROLYN H. TUOHY, accidental logics: The Dinamics of Change in the Health Care arena in the United STATES, BRITAIN, AND CANADA (1999).

4. Readers should not be misled by controversies about the precise meaning of a medical care "crisis." In the 1993-94 period, for example, the media first seized on the ambiguously worded doubts that Sen. Daniel Patrick Moynihan expressed about the relative importance of welfare and health care reform in the Clinton Administration's priorities. The media made the issue front-page news. Senator Robert Dole, sensing the opportunity to challenge the ambitious scope of the Clinton reform bill, questioned whether the nation's medical problems were of "crisis" proportions. Soon thereafter, all of the major political leaders agreed that the problems were serious enough to justify debate about reform and the semantic duel quickly ended. The whole episode typified the muddled state of commentary about American medical care but did not seriously challenge the consensus that substantial change is necessary. The same applies to disputes in 2005 about the scale of America's problems; they exist at a level more than enough to warrant reform.

5. For more on the public desire for substantial change in health care, see Robert J. Blendon \& John M. Benson, Americans' Views on Health Policy: A Fifty-Year Historical Perspective, Health AFF., Mar.-Apr. 2001, at 33-46. 
administratively workable program of reform. That is as true in 2005 as it was in 2003.

\section{B. History: Lesson or Lamentation? ${ }^{6}$}

Indeed, the task of substantially changing the rules of American medical care is one of the most difficult challenges reformers face. At four other moments in twentieth-century American politics (excepting 1993-94), reformers and their presidential backers tried to effect change. In the Progressive Era, during the New Deal, under President Truman, and during the early 1970 s, advocates thought universal health insurance was imminent and were bitterly disappointed. Now in 2005, as before, entrenched stakeholders can be counted on to block national health insurance by skillfully manipulating our deepest fears to protect what they regard as their interests.

Yet, before an administration and the Congress can meet the challenges of workable reform, they have to resolve-or at least cope with - some of the nastiest ideological and budgetary conflicts available in American politics. What might be learned by reviewing earlier efforts by those committed to broad medical reform, but faced with seemingly intractable problems of substance, symbol, and support? Those who do not learn the lessons of history, academics regularly intone, are doomed to repeat past mistakes.

The health reformers of the Progressive Era were convinced that broadened health insurance, financed and administered through social insurance, held the key to improved health, medical progress, and economic security. But theirs was an elite view, helped in the pre-World War I period by the apparent acquiescence of the American Medical Association ("AMA"). Yet, it turned out, there was nothing like a massive popular consensus on the need for change and, after the AMA turned against the idea, the reform movement withered from frustrating efforts for state initiatives to mere academic discussion. A negative elite consensus on the need for change, it appears, is a necessary but not sufficient condition for the enactment of reform programs.

6. The author has adopted with permission Part II.B-G from Marmor, supra note 2, at 194-97. 


\section{The Lost Reform: Compulsory Health Insurance in the New Deal}

The agony of the Great Depression opened up enormous opportunities for change in American domestic politics. President Roosevelt led the way, commissioning expert group after expert group to take on reforms needed in welfare, unemployment, agricultural failure, banking collapse, and in the institutions of economic security more generally. The opening for universal health insurance came in 1935 with the famous Committee of Economic Security ("CES"). A cabinet-level special committee, the CES took a year to review the circumstances of welfare, unemployment, child health, and old age poverty and to arrive at a package of programmatic suggestions. They did their work with admirable skill and timeliness, fashioning workable ideas from a farflung research investigation of various methods of resolving these difficult problems. Unemployment and welfare were the most pressing and obvious problems; retirement benefits, though they have loomed much larger in subsequent decades, did not dominate their deliberations. President Roosevelt hesitated with compulsory health insurance, worried that the presumed opposition of the AMA and their ideological allies might jeopardize the success of the bulk of his social insurance reform package. $^{7}$ So it was that the committee refrained from even studying health insurance reform, leaving that to the congressional advocates who, in the next decade, would, under the banner of the Murray-WagnerDingell bill, frustratingly try to generate majority support in the public and in the Congress. ${ }^{8}$

\section{From National Health Insurance to Medicare: The Dogged Retreat}

President Truman's experience with national health insurance was no less frustrating. He fought the election battle of 1948 with national health insurance prominent among his proposals for a Fair Deal. But he faced, during the election and after, a barrage of ideological criticism that linked national health insurance with socialism, communism, and the recently demonized Soviet Union. After some years of facing certain

7. See, for elaboration on this episode, Alan Derickson, Health SECurity for All: DREAMS OF UNIVERSAL HEALTH CARE IN AMERICA 52-71 (2005).

8. The American development of social insurance-and the character of the legislative initiatives of the 1930s-is illuminatingly (and briefly) discussed by one of Social Security's most illustrious administrators, Robert Ball, in The Original Understanding of Social Security: Implications for Later Developments, in SOCIAL SECURITY: BEYOND THE RHETORIC OF CRISIS 17 , 17-39 (Theodore R. Marmor \& Jerry L. Mashow eds., 1988). 
defeat in the Congress, Truman turned his executive advisors in 1951 to a more modest goal: a health insurance program for social security recipients that would in time (fourteen years) become the Medicare program of 1965.

During Truman's presidency, the general public was, according to the polls, always supportive of government health insurance. But this support was neither deep nor informed. Socialized medicine was a tag that scared many, enough so that no amount of presidential enthusiasm seemed adequate to generate majority support in the Congress. What we later came to know as the conservative coalition linked opposition from powerful, conservative Southern Democrats and their ideological counterparts among Republicans. This was enough to defeat every attempt at universal coverage-whether for all Americans or just the over-65s-until 1965.

The fight over Medicare illustrates one rare set of conditions sufficient for successful reform, even partial reform. Before 1965, the conservative coalition remained formidable. The Democratic landslide of 1964 swept away the key conservative bases of institutional power: dilatory tactics symbolically represented by the Rules Committee, control of other key committees without threat from the Democratic caucus, and an ideological balance in the Congress as a whole less liberal than Presidents Kennedy or Johnson. But the massive electoral shift of 1964 held a lesson for future reformers. A fully sufficient condition for reform proved to be the two-to-one Democratic majority in the House of Representatives, a margin large enough to contain within it an issue majority on Medicare. In retrospect, Medicare might well have emerged a bit later from the narrow defeats of the early 1960s; the election of 1964 prevents us from knowing for sure whether and how long such a counterfactual development might have taken. ${ }^{9}$

\section{E. The Nixon Years: Seeming Consensus, Undeniable Disappointment}

By 1970 , the topic of health reform had shifted back from Medicare to national health insurance once again. Though it is difficult for many to remember, the striking feature of the 1970-74 years was the intense competition among proponents of different forms of universal health insurance. There was the catastrophic proposal Senators Long and Ribicoff advocated. There was also the Kennedy-Corman bill that so

9. See Theodore R. Marmor, The Politics of Medicare 45 (Aldine DeGruyter ed., 2d ed. 1970 ) for the interpretation, drawn from my own writing on the topic. 
closely exemplified Canada's national program as of 1971. And there was the Nixon administration's plan for mandated health insurance for employed Americans known then as the Comprehensive Health Insurance Plan, or CHIP.

The lessons of this period are surely relevant to American circumstances today. Reform failed because shifting coalitions defeated every attempt at compromise-cycling negative majorities, we might say in political science jargon. The majority that agreed on the need for reform consisted of factions committed to different proposals. The more modest proposals - like the Long-Ribicoff catastrophic bill-seemed too limited to those who wanted to translate the negative consensus into universal, broad coverage. The proposal for employer-mandated insurance-similar in financing to what President Clinton later proposed-seemed too indirect, incomplete, and incapable of cost control to those favoring more straightforward forms of national health insurance. Even Senator Kennedy, who moved from the more ambitious version of national health insurance (the Kennedy-Corman bill) to a compromise plan that he and the powerful Wilbur Mills could accept, was incapable of generating majority support among a coalition of liberal and conservative Democrats.

It is no wonder that so many from that period were so anxious to act in the early 1990s and why so many now are pointing to the need for reform. But the caution here is that the lessons of the 1970s are multiple, not simple. What might well have made sense then-namely mandated, employment based coverage-need not define the limit of what is possible 30 years later. Indeed, figuring out the impact of three decades of frustration with partial reform is the major task facing reformers today.

\section{F. The Contemporary Task: Daunting But Doable?}

The lessons of history are never simple. What worked once may not, in changed circumstances, work again. What failed may succeed. But some constants in American politics are always relevant to lesson drawing.

First, compulsory health insurance-whatever the details - is an ideologically controversial matter that involves enormous symbolic, financial, and professional stakes. Such legislation does not usually emerge quietly or with broad bi-partisan support, either here or elsewhere. The politics of national health insurance not only expresses ideological and partisan differences; it also gives visible form to what 
political groupings stand for, and in that sense policy convictions and values shape the politics of the issue.

Legislative success in this arena normally requires active presidential leadership, the commitment of an administration's political capital, and the exercise of all manners of persuasion and arm twisting. President Roosevelt was unwilling to do this in the New Deal, and President Nixon refrained from doing it in the early 1970s. President Clinton gave enormous attention to health reform, but proceeded as if he were negotiating with an Arkansas legislature and could make a sufficient number of private deals to secure a majority. As we are well aware, he famously failed.

President Johnson was fully willing to use all his legendary legislative energy in 1965, but the composition of the Congress then hardly made it necessary. Giving priority to the Medicare bill (with H.R.1 and S.1 as the numerical symbols) represented President Johnson's determination as well as his concentration on Medicare as the centerpiece of his first year's legislative campaign.

Second, the limits of political feasibility are far less distinct than beltway commentators seem to recognize. Political constraints are real, but they do not submit to estimates as precise as the budgetary work of the CBO. For example, the Johnson Administration, anxious to make sure its first step would be overwhelmingly acceptable in 1965, requested hospital benefits under Medicare only. But the oddest thing happened. A combination of liberals anxious to make the Medicare program broader and conservative Democrats wishing to head off step-by-step expansion later agreed to a wider reform than Johnson requested. Not only was physician insurance added to Medicare by the Ways and Means Committee (what we know as Part B), but Medicaid emerged as part of an unexpected "three-layer cake." No one should assume that the substantive and ideological package sent to the Congress is fixed in stone. And no one should treat such "resultants" as the purposeful work of skillful entrepreneurs. Resultants emerge, and the lesson is not that anything is possible but rather that feasibility estimates must acknowledge considerable uncertainty.

Third, the role of language and emotive symbols in this policy world cannot be overestimated. How the president reaches out to the public, what counts in the evening news and the morning newspapers as the central reform themes, and whether the Congress faces a determined grass-roots movement all shape the legislative outcome, and, even more importantly, whether the resultant is sufficiently coherent and implementable to satisfy the expectations for reform. Pressure groups 
that can prevail in quiet politics are far weaker in context of mass attention, as the AMA regretfully learned in the Medicare battle of 1965 .

But the central lesson of the past-of both defeats and victories like Medicare-is cautionary in a different sense. It is wise to wait if what is acceptable is not workable. It is foolish to hesitate if what is workable can be made acceptable. If the central elements of a workable plan are acceptable, the pace of implementation can be staggered. American political history in this area shows that the opportunities for substantial reform, however, are few and far between, but precious enough to make squandering close to a sin.

\section{G. Reform and Political Science}

The role of political scientists (and political science) in the twentiethcentury battles over universal health insurance is not a subject to which much attention has been paid. That, of course, is no reason to ignore it.

Until the Truman period, political scientists did not play a prominent intellectual role in the debate over what form, if any, government health insurance should play in the American version of a welfare state. The social insurance reformers of the Progressive Era took their cues from Europe, especially Germany, and included in their numbers lawyers, public health figures, insurance experts, and what were then known as political economists. By the New Deal, there were two major streams of intellectual commentary: those like I.S. Falk from public health and those like Edwin Witte, Selig Perlman, and Abraham Epstein from the specialized academic field of social insurance. At that time, many American universities, particularly land grant ones, had prominent experts in social insurance within their economics, sociology, and history departments. At the University of Wisconsin particularly, this expertise was transferred to state reform action (in unemployment insurance, for example) and to the New Deal reforms, where Professor of Economics Edwin Witte became the executive director of the Committee on Economic Security.

The persistent clash over the Murray-Wagner-Dingell proposal for national health insurance between 1939 and 1948 brought health politics to countrywide media attention. And, in the wake of that, political scientists concerned with public opinion and the operation of pressure groups in American politics came to address national health insurance more directly. The AMA, then the leading critic of "government medicine," expended considerable resources trying to defeat the Truman reform plan and became a prominent example of interest group exertion of power in America's fragmented political system. Stanley Kelley's 
Professional Public Relations and Political Power addressed this phenomenon directly, supplementing what had become the conventional explanation by journalists for why the United States, unlike most other industrial democracies, rejected national health insurance. ${ }^{10}$

Kelley's interest in the battles of the 1940s was followed by considerable attention to the long struggle over Medicare. Books by political scientists Feingold, Feder, and Marmor addressed the origins, enactment, and early implementation of this controversial program of the Kennedy-Johnson years. But, for all the attention Medicare's legislative struggle generated, political scientists have largely ignored the administrative experience of that program. ${ }^{11}$ The analysis of subsequent disputes over America's so-called "health crisis" was largely ceded to other fields.

There are exceptions to be sure: Larry Brown's writing on the politics of the HMO movement; Jim Morone's work on health planning; Mark Peterson's book on the health politics of the 1970s and 1980s; and Larry Jacobs's book comparing the political struggle over the NHS and Medicare. More recent examples are Larry Jacobs and Robert Shapiro's Politicians Don't Pander, ${ }^{12}$ Jacob Hacker's Road to Nowhere, ${ }^{13}$ Jon Oberlander's Political Life of Medicare, ${ }^{14}$ and Jim Morone's Hellfire Nation. ${ }^{15}$ But the general point remains.

Economists particularly expanded into the health policy arena in the 1960 s, not surprisingly following the expanded market for research on this growing industry. Whether this market development has illuminated our policy issues is a controversial matter, but it would be surprising to find an essay - like Dan Fox's critique of modem health economicswritten on the role of political science in the past twenty years of health policy disputes.

The irony, however, is this: as we contemplate substantial health reform in the 21 st century, assumptions about political feasibility are central to the policymaking arguments. Those who most regularly voice

10. Stanley Kelley, Professional Public Relations and Political Power 160-69 (1956).

11. The clear exception is Jonathan Oberlander's book, The Political Life of Medicare. See Jonathan OBERLANDER, The POLITICAL LIFE OF MEDICARE 145-55 (2003) (discussing Medicare's pressure by private interests).

12. LaWrence R. Jacobs \& Robert Y. Shapiro, Politicians Don't Pander: Political MANIPULATION AND THE LOSS OF DEMOCRATIC RESPONSIVENESS (2000).

13. Jacob hacker, The RoAd to Nowhere: The Genesis of President Clinton's Plan FOR HEALTH SECURITY (1997).

14. OBERLANDER, supra note 11.

15. James A. Mornone, Hellfire Nation: The Politics of Sin in American History (2003). 
opinions about this matter tend not to be professional political scientists. Economists like Henry Aaron, Uwe Reinhardt, and Mark Pauly-among many others-seem reasonably sure they know American politics well enough to evaluate the prospects of particular reform proposals.

What is striking about such commentary is the thinness of the evidence on which such judgments are made. None of the economists I have cited have themselves studied the changing constraints of American politics. None of them have systematically investigated the role of public opinion in policy making in ways, for example, illustrated by the work of Page, Shapiro, or Jacobs. But none of them appear to have doubt that their judgments are more than conventional wisdom applied to an arena of politics that has confused even the most meticulous of scholars. I leave it to historians to wonder why this should be the case.

There is, however, another side to the current story. A number of political scientists in the early 1990s joined forces to comment on the claims and counterclaims about reform. Organized in reaction to the Jackson Hole Group and known informally as the "No Holes Group," these policy commentators were in fact largely political scientists. Their names will be familiar to those interested in the place of medical care in American political studies: Larry Brown of Columbia, Tom Oliver of Maryland, Jim Morone of Brown, Mark Peterson of Pitt, Larry Jacobs of Minnesota, Christa Altenstetter of CUNY, David Wilsford of Georgia Tech, Deborah Stone of Dartmouth, Joe White at Brookings, and myself.

This group, augmented by a number of other sociologists, economists, and lawyers, represents the culmination of a development dating back to the late $1960 \mathrm{~s}$ - the initiation of a Committee on Health Politics. From that beginning emerged The Journal of Health Politics, Policy, and Law and a considerable amount of scholarship. What the "No Holes Group" illustrated is the movement from academic inquiry to a politically more active role; one evidenced not simply by published work, but congressional testimony, media appearances, and other forms of policy participation. Whether that shift in effort will be influential is something no one can be sure about at this point. But it is interesting that in 2005, the "No Holes Group" is being revived.

\section{SEARCH FOR COMMON GROUND AND FEASIBLE REFORM}

My suggestion for reform now is that we seek a truce among the health policy analysts and make a serious search for a different strategy. My proposal is first to organize a special commission of seasoned and gifted, but not expert, members. Their major task would be to fashion a 
set of proposals for American health financing reform that ought to command broader support than the failed efforts of the last decades.

For example, a starting point would be to lay out a common set of goals that any one of the five most prominent approaches to health reform might plausibly be said to share. Below is my initial list, but I have not elaborated on their character in any detail. All I want to accomplish here is the enumeration of what appears to be common ground and to exclude purposes that fall outside this set.

1. Universal Coverage: i.e., protection for all US citizens and legal aliens against the catastrophic expenses of illness and injury.

2. Coverage of Universally Understood Medical Care: i.e., hospital, physician, and pharmaceutical expenses, ordinarily defined.

3. Avoid Fostering a Raid on the National Treasury: i.e., program features that mitigate any expected explosion of health care outlays as a consequence of the reform.

4. Portable Coverage: i.e., protection when outside one's state, possibly outside the country, for catastrophic expenses.

5. Public Accountability: i.e., an institutional provision for determining to whom and to what organization would violations of the above standards be addressed.

From this starting point, the task of review would be to select perhaps five prominent proposals for universal health insurance and sort out the common ground among them. I have the following in mind as examples of well-known reform ideas: 1) tax credit reforms to extend health insurance - a position associated prominently with Mark Pauly; 2) competing health finance institutions with universal financial support-a conception identified broadly with Alain Enthoven; 3) Medicare for All, an extension of the present program - a proposal made by James Morone of Brown; 4) health savings accounts with catastrophic backup insurance- $a$ version of which was in the Medicare Modernization legislation of 2003; and 5) extensions of Medicaid and Child Health insurance, which are basically incremental steps from where reform has been recently. The next phase is to take up fears, not common ground.

\section{THE OTHER PERSPECTIVE: SERIOUS CONCERN FOR THE WORST FEARS OF THE OTHER PROPONENTS}

The worst fear each advocate has for the other four models of universal insurance coverage is, from the standpoint of increasing consensus, an important topic. Very few if any of the reform proposals of the past thirty years have addressed this matter. Yet, if one wants to increase the likelihood of reform, attending to fears is as important as 
highlighting common ground. Attending to the fears, however, is not a matter of listing objections or excluding disputed ideas.

Rather, the proposal here is to provide a serious answer (not concession) to the fear. For instance, if the greatest fear of a proposal for extending Medicare to all citizens is that it will produce extraordinary increases in total health expenditures, the staff would have to present means by which that could plausibly be avoided. Such attending to fears is not meant to produce agreement on what is best. Rather, it is to force attention to problems each reform proposal highlights for critics. And it further suggests means by which the opposition to reforms can be lessened where the "answers" given are well-informed and organizationally, as well as politically, "feasible." The question of what would count as a well-informed and feasible policy response to fears is precisely the job of the commission and its staff.

\section{CONCLUSION}

The idea of a commission is hardly new in American politics. Indeed, it is important to note American frustration with commissions as sources of delay rather than initiative. Disappointment, however, does not mean a useful commission is impossible. It would be worth reflecting on the fate of the Canadian Royal Commission of 1964-66 as a mode of deliberation, careful research, and the promotion of an operational and feasible form of national health insurance. Chaired by Justice Emmette Hall of the Saskatchewan Supreme Court, the body produced a set of documents that brought together Canada's history of financing medical care, the experience of other rich democracies with the topic, and crafted a model bill that surprisingly passed a Canadian national legislature despite the substantial opposition of the Canadian Medical Association and its ideological allies across Canada.

Political judgments about particular reform proposals are products of personal experience, political ideology, and local economic and social conditions. These factors change substantially as one moves about the United States. If change is to be workable and acceptable, it must take into account the real differences between New York and Idaho, Wisconsin and Louisiana. Moreover, what is operational varies less than what is politically acceptable and financially plausible at any one time. Simply considering the following four-fold combination of political and economic circumstances alerts one to this consideration. Vary the economic conditions, for example, between two states: high rates of economic growth and recession or near recession rates. Combine those two criteria with two states of the distribution of political and ideological 
dominance: for example, Democratic or Republican control of the executive and at least one of the legislative bodies. The resulting fourfold table does not exhaust the possibilities quite obviously. Political stalemate (or, if you prefer, a more balanced power situation) could obviously produce two more cells. But the main point should be obvious. What is likely to win majority support would not be the same under all four conditions. And the point, therefore, of the effort is to have available a version of a plausible health system reform that would command wider support than otherwise because of its commitment to common ground and answering serious objections. That, at least, is what this political and policy analyst would urge others to consider. 